\title{
Article \\ Particle-Bound Mercury Characterization in the Central Italian Herbarium of the Natural History Museum of the University of Florence (Italy)
}

\author{
Francesco Ciani ${ }^{1}\left(\mathbb{D}\right.$, Laura Chiarantini ${ }^{1,2}{ }^{(}$, Pilario Costagliola ${ }^{1,3}$ and Valentina Rimondi $1,3, *(\mathbb{D})$ \\ 1 Dipartimento di Scienze della Terra, Università di Firenze, Via G. La Pira 4, 50121 Firenze, Italy; \\ francesco.ciani@unifi.it (F.C.); laura.chiarantini@unifi.it (L.C.); pilario.costagliola@unifi.it (P.C.) \\ 2 Centro di Servizi di Microscopia Elettronica e Microanalisi (M.E.M.A.), Università di Firenze, Via G. Capponi, \\ 50121 Firenze, Italy \\ 3 CNR-IGG, Via G. La Pira 4, 50121 Firenze, Italy \\ * Correspondence: valentina.rimondi@unifi.it
}

check for updates

Citation: Ciani, F.; Chiarantini, L.; Costagliola, P.; Rimondi, V. ParticleBound Mercury Characterization in the Central Italian Herbarium of the Natural History Museum of the University of Florence (Italy). Toxics 2021, 9, 141. https://doi.org/ $10.3390 /$ toxics 9060141

Academic Editors: Laura Marziali and Laura Fantozzi

Received: 7 May 2021

Accepted: 11 June 2021

Published: 15 June 2021

Publisher's Note: MDPI stays neutral with regard to jurisdictional claims in published maps and institutional affiliations.

Copyright: (c) 2021 by the authors. Licensee MDPI, Basel, Switzerland. This article is an open access article distributed under the terms and conditions of the Creative Commons Attribution (CC BY) license (https:/ / creativecommons.org/licenses/by/ $4.0 /)$.

\begin{abstract}
Museums air quality can be negatively affected by treatments with heavy metals compounds employed to prevent pest infestations. Among these, the past use of mercury dichloride $\left(\mathrm{HgCl}_{2}\right)$ on herbaria artifacts currently produces high levels of indoor atmospheric gaseous mercury $\left(\mathrm{Hg}^{0}\right)$ and possibly of particulate bound $\mathrm{Hg}(\mathrm{PBM})$, i.e., the particulate matter containing $\mathrm{Hg}$. This study evaluates the PBM pollution in the Central Italian Herbarium (Natural History Museum of the University of Florence, Italy), characterizing the size range and chemical speciation with SEM-EDS microanalysis. The analysis of the total $\mathrm{Hg}$ concentration in the samples allowed to calculate the workers exposure risk to this pollutant. PBM is almost totally classifiable as fine particulate with a significant dimensional increase in a period of scarce attendance of the Herbarium rooms. The microanalysis indicates that $\mathrm{Hg}$ is essentially bound to $\mathrm{S}$, highlighting the change of $\mathrm{Hg}$ speciation from the original association with $\mathrm{Cl}$. The average $\mathrm{Hg}$ concentration reveals a potential health risk for workers as result of multiple Hg exposure pathways, mainly by ingestion. The study provides information for characterizing PBM pollution that could affect a workplace atmosphere and a useful basis to evaluate and correctly design solution strategies to reduce the contamination levels and protect workers' health.
\end{abstract}

Keywords: mercury; trace elements; particulate matter; indoor air quality; pollution; museum

\section{Introduction}

The increasing attention devoted to the indoor air quality is the direct result of the high amount of time that people spend indoors during the day (about $88 \%$ for adults and $71-79 \%$ for children) in addition to the potential occurrence of airborne chemical and biological pollutants [1]. Indoor chemical contaminants are mainly due to anthropogenic sources, such as cooking/heating, tobacco smoking and the use of paints or cleaning products, while biological contaminants are mainly allergens, such as pollen grains and hair, or organisms, such as molds, mites or insects [2].

Indoor air quality is especially important in environments, such as museums, where the health of both visitors and workers must be protected. As evidenced by Schieweck [3], the specificity of the museum, i.e., the type of collections it contains and how they were treated to guarantee their protection, influence the air inside. This is, for example, the case of natural history collections where heavy metals (i.e., metals with atomic number greater than 20 and elemental density greater than $5 \mathrm{~g} \mathrm{~cm}^{-3}$, e.g., [4]) contamination is often observed as a direct consequence of pesticide treatments or taxidermal preparations $[5,6]$. This issue especially concerns mercury $(\mathrm{Hg})$, which was highly employed in botanical collections, as shown in several studies carried out over the past few decades [6-15]. 
Mercury levels inside the atmosphere of herbaria are mainly due to the use of corrosive sublimate, an alcoholic solution of $\mathrm{Hg}$ dichloride $\left(\mathrm{HgCl}_{2}\right)$, where plant samples were dipped to prevent cryptogamic or animal infestations until the middle of the last century [16]. The decomposition of $\mathrm{HgCl}_{2}$ causes the release of elemental gaseous $\mathrm{Hg}\left(\mathrm{GEM}, \mathrm{Hg}^{0}\right)$ resulting in $\mathrm{Hg}^{0}$ levels $\geq 1000 \mathrm{ng} \mathrm{m}^{-3}$, i.e., the annual average reference value reported by World Health Organization [17] for inorganic $\mathrm{Hg}$ in the air, which can pose a health hazard for workers and museum visitors [15]. The reduction of $\mathrm{Hg}^{2+}$ to $\mathrm{Hg}^{0}$ has been attributed to several mechanisms: in the case of $\mathrm{Hg}$ in soils, Gustin [18] suggested a temperature-driven reduction, while Scholtz [19] assumed a photolytic reaction; in other studies carried out in herbaria, Oyarzun [9] hypothesized an enzymatic reduction, while Havermans [13] suggested a reduction reaction triggered by the cellulose of the paper on which plant samples are stored.

Mercury is ubiquitously distributed in the environment, naturally occurring in the Earth's crust at average concentrations of about $0.05 \mathrm{mg} \mathrm{kg}^{-1}$ [20]. Mercury in the atmosphere is present both as gaseous forms, i.e., GEM and reactive gaseous $\mathrm{Hg}\left(\mathrm{RGM}, \mathrm{Hg}^{2+}\right)$, and as particulate bound $\mathrm{Hg}$ (PBM). GEM represents the most abundant (>95\%) form of $\mathrm{Hg}$ in the atmosphere, with high stability and long lifetime (from 0.5 to 2 years) thanks to chemical inertness [21]. Due to this long persistence, $\mathrm{Hg}$ is considered one of the major global environmental pollutants [22].

PBM consists of all airborne particulate containing $\mathrm{Hg}$, including both stable condensed and gaseous forms adsorbed on atmospheric particulate matter (PM); it is operationally sampled and quantified by pulling air through a glass fiber or a quartz filter [23]. PBM usually includes all those particles with a diameter $<2.5 \mu \mathrm{m}$, even if its characterization depends on the pore size of the filter used for its collection [24]. The accurate dimensional characterization is then essential to estimate the dry deposition of PBM, as well as any other particulate pollutant; the particles diameters directly influence gravitational sedimentation and the PBM residence time in the atmosphere [25]. In addition, PBM chemical speciation, as well as for the other $\mathrm{Hg}$ forms, is fundamental to understand PBM bioavailability and therefore the effects on human health [26].

The study reported in this paper has been conducted in the Central Italian Herbarium, the botanical section of the Natural History Museum of the University of Florence (Italy), located in the historical center of the city (Figure 1a): with over 4.5 million plant samples, this herbarium is the largest in Italy and the tenth worldwide $[27,28]$.
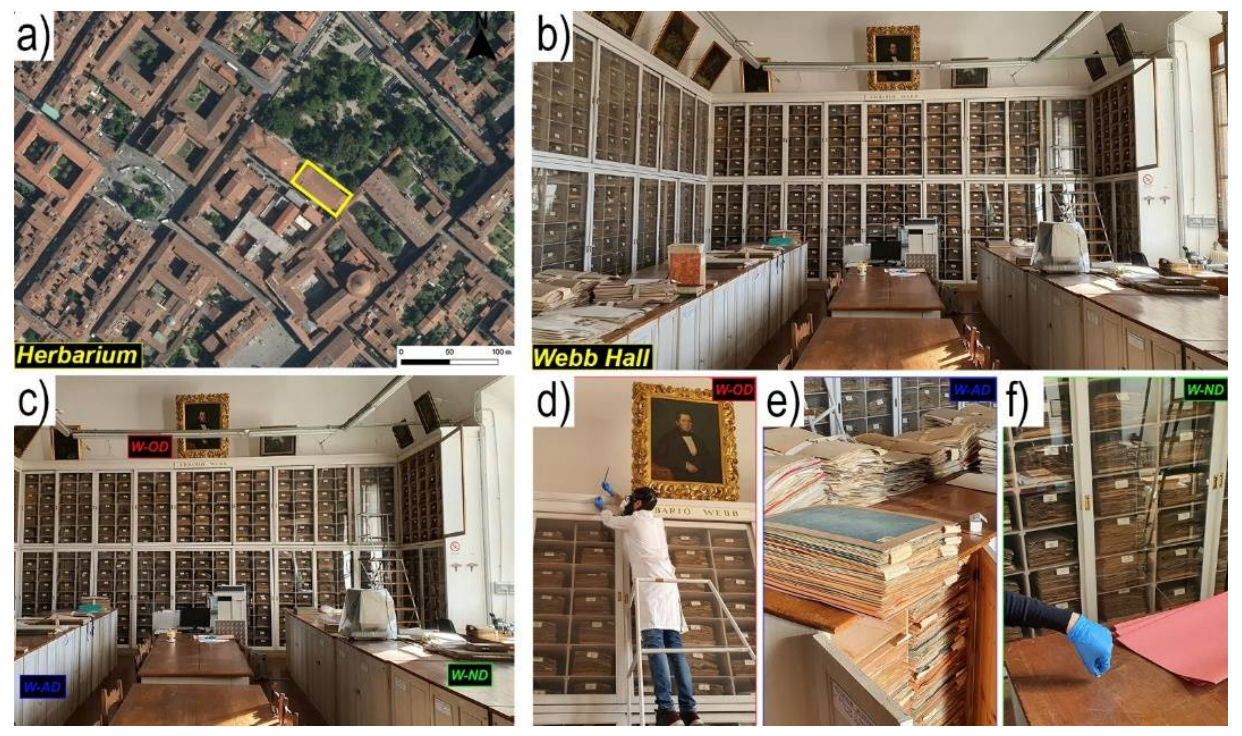

Figure 1. (a) Geographical location of the Central Italian Herbarium (Florence, Italy); (b) the Webb Hall; (c) detail location of the sampling points in the Webb Hall for the different dust types: (d) old-dust (W-OD), (e) almost-new dust (W-AD), and (f) new-dust (W-ND). 
The aims of this paper are: (i) to evaluate the presence of $\mathrm{Hg}$ pollution in the PM of a working environment such as that of a botanical museum (ii) to characterize $\mathrm{Hg}$ particulate for size distribution and chemical composition; and (iii) to estimate the potential exposure risk for the museum's workers exposed to PBM.

To our knowledge, this is the first attempt to characterize the morphometric and chemical speciation of $\mathrm{Hg}$ particulate in a botanical museum.

\section{Materials and Methods}

\subsection{Study Site}

The Central Italian Herbarium of Florence was founded in 1842 and hosts some historical collections, like the Herbarium Cesalpino (16th century), the Herbarium Micheli-Targioni (18th century), the Herbarium Webb (18th-19th century), and the Herbarium Beccari (19th century). $\mathrm{HgCl}_{2}$ was used as pesticide since the Herbarium's foundation and despite this practice being abandoned more than a hundred years ago [29], recent studies still proved the persistence of high GEM concentrations (>50,000 $\mathrm{ng} \mathrm{m}^{-3}$ ) [15]. The highest level of GEM was achieved in the so-called Webb Hall of the Herbarium (Figure 1b), hosting some of the most ancient and precious plant collections, such as the Webb and Beccari herbaria.

\subsection{PBM Ampling and Analysis}

PBM sampling was carried out in October 2018 and in September 2020. In 2020, the sampling occurred soon after the lockdown period (March to May 2020) due to the COVID9 pandemic. Dust samples were collected in the Webb Hall (acronym for samples name W) dabbing different areas (furniture, wall cornice, sample cabinet, study table) using a double-sided tape fixed on a stub. At each site, the same superficial area (ca. $\left.1 \times 1 \mathrm{~m}^{2}\right)$ was sampled (three replicates for each sampling site) and the same number of dabbings (five) was done. Samples were roughly divided according to their deposition time (Figure 1c): (i) old dust (OD) from surfaces never dusted or hidden surfaces, like the frames of paintings hanging in the Webb Hall (Figure 1d); (ii) almost-new dust (AD), collected from surfaces cleaned approximately every two months, such as the cabinets that house plant samples (Figure 1e) or on book shelves; and iii) new dust (ND), recovered from surfaces cleaned about twice a week, such as desks and tables (Figure 1f). In addition, only during the 2020 sampling campaign, wooden pieces of a cabinet containing plant samples (inside which $>50,000 \mathrm{ng} \mathrm{m}^{-3}$ of $\mathrm{Hg}^{0}$ were detected by Cabassi [15]) and paint fragments scraped from a wall were taken in the Webb Hall. As background sites, some dust samples (OD, AD, and ND) and wall paint fragments were also collected from rooms that host the Geomineralogy (acronym for samples name G-) and Botanical libraries (acronym for samples name B-) of the University of Florence, located on the ground level and first floor of the same building hosting the Central Italian Herbarium. It should be noted that the Botanical library hosted some Hg-poisoned plants collections in the first years following the Herbarium's foundation (1842), and also in recent years for temporary exhibitions [27]. The complete list of samples with detailed descriptions and locations is shown in Table 1.

Dust samples were analyzed using scanning electron microscopy coupled to energy dispersive spectroscopy (SEM-EDS), using a model EVO-MA15 Zeiss, equipped with Oxford INCA 250 microanalysis software, located in the Interdepartmental Center for Electron Microscopy and Microanalysis Services (M.E.M.A.) of the University of Florence. All samples were metallized with a few nanometers of graphite and analyzed at a 15-kV acceleration voltage, $700 \mathrm{pA}$ electron current, and at a 9-10 mm working distance. The analysis protocol was developed to standardize the measurements and quantify the particles composed of heavy metals in a faster and accurate way. Samples were previously investigated using an automatic procedure (Oxford INCA Feature automated analysis) that allowed to select the standard surface area of each sample to be investigated and a suitable magnification to identify the particles. Selecting backscattered electrons images with an appropriate black and white image threshold, the program is able to identify all particles comprising the selected thresholding levels, to morphologically measure them, 
to perform a rapid EDS (10-s of live-time) analysis, and thus chemically classify all dust particles. Heavy metal dust particles were recognized as light grey areas using backscattered electrons images with a contrast of $60 \%$, brightness of $5-10 \%$, and a threshold shade of grey (between 80 and 250) able to include all particles with an average atomic number (Z), heavier than $\mathrm{Ba}$ (reference standard $\mathrm{BaSO}_{4}$ ). In each stub, a total surface area of $4 \mathrm{~mm}^{2}$ was analyzed, observed in two distinct randomly selected $2 \times 1 \mathrm{~mm}^{2}$ areas at $1000 \times$. These methods allowed the isolation of dust particles characterized by a high average $Z$, comprising (but not exclusively) those containing Hg. It has to be stressed that, on the basis of backscattered electrons (BSE) thresholder images, the dimension (equivalent circular diameter, ECD) of the identified particles was smaller than the $\mathrm{X}$-ray generation volume (i.e., the volume from which $\mathrm{X}$-rays are produced). We could estimate an interaction volume with a diameter of about $0.8-1.1 \mu \mathrm{m}$ (respectively at $10-20 \mathrm{kV}$ acceleration voltages) for heavy elements/compounds (density $>8 \mathrm{~g} \mathrm{~cm}^{-3}$, i.e., $\mathrm{Cu}$ ), and even greater (some microns) for light elements. To restrict SEM-EDS microanalyses to the volume of $\mathrm{Hg}$ particles, minimizing the contribution of the surrounding phases, a more detailed microanalysis (30-s of live-time) was selectively conducted on the stub surface areas where the largest Hg-particles (i.e., ECD $>1 \mu \mathrm{m}$ or the largest for each sample) was found. All elements were re-calculated using the microanalysis software, which used the XPP matrix correction scheme developed by Pouchou and Pichoir [30]. This is a Phi-Rho-Z approach which uses exponentials to describe the shape of a $\varphi(\rho z)$ curve. The procedure is a "standard-less" semi-quantitative analysis employing pre-acquired standard materials. The monitoring of the analytical conditions (i.e., filament emission) was conducted with repeated analyses of a Co metallic standard.

Table 1. Location and description of the sampling sites.

\begin{tabular}{|c|c|c|c|}
\hline Sampling Site & Sample Name & Dust Type & Location \\
\hline \multirow{5}{*}{ Webb Hall } & W-OD & old & Above the top shelf of the closet surrounding the Webb Hall \\
\hline & W-AD & almost-new & On the surface of a sample pack inside a cabinet of the Webb Hall \\
\hline & W-ND & new & On the shelf of a cabinet hosting herbaria samples of the Webb Hall \\
\hline & $\mathrm{W}-\mathrm{W}$ & wood & Wooden pieces of a cabinet of the Webb Hall \\
\hline & W-P & paint & Paint fragments scraped off the wall of the Webb Hall \\
\hline \multirow{4}{*}{ Botanical library } & $\mathrm{B}-\mathrm{OD}$ & old & On the upper frame of a cabinet in the Botanical library \\
\hline & B-AD & almost-new & Inside a closet of the Botanical library \\
\hline & B-ND & new & On the support surface of a cabinet in the Botanical library \\
\hline & B-P & paint & Paint fragments scraped off the wall of the Botanical library \\
\hline \multirow{4}{*}{ Geomineralogy library } & G-OD & old & On the upper frame of a cabinet in the Geomineralogy library \\
\hline & G-AD & almost-new & On a book shelf on the upper balcony in the Geomineralogy library \\
\hline & G-ND & new & On a study table in the Geomineralogy library \\
\hline & G-P & paint & Paint fragments scraped off the wall of the Geomineralogy library \\
\hline
\end{tabular}

Size differences among the Hg-particles were investigated using the non-parametric Mann-Whitney test, due to the non-normal distribution of data acquired in this study. The analyses were carried out using R-Studio software [31] with a significance level equal to 0.05 for all procedures.

\subsection{Mercury Concentration and Health Risk Assessment}

The total $\mathrm{Hg}$ concentration was determined from the dust samples collected from both the Webb Hall and the blank site (i.e., Geomineralogy library) using a direct $\mathrm{Hg}$ analyzer (Milestone DMA-80 evo, Department of Earth Sciences, University of Florence). The analysis was based on sample combustion, the pre-concentration of $\mathrm{Hg}$ on a gold amalgamator that was subsequently heated for $\mathrm{Hg}$ quantification with atomic absorption spectrometry (AAS). Dust (three replicates for each sampling site) for analysis was collected on the same double-sided tape used in the SEM-EDS analyses. To recover the sample weight, the tape was weighed before and after the dust collection using a 6 significant 
digits balance. A portion of a clean tape (blank) was also analyzed for $\mathrm{Hg}$, and the value obtained subtracted from the dust samples. Analysis accuracy was verified using an international standard (BCR-280R, $\mathrm{Hg}=1.46 \pm 0.2 \mathrm{mg} \mathrm{kg}^{-1}$ ), and the error was within $10 \%$.

To quantify the non-carcinogenic risk for workers from exposure to $\mathrm{Hg}$-particles of the Herbarium dust, the average daily doses (ADD, $\mathrm{mg} \mathrm{kg}^{-1}$ day $^{-1}$ ) for the three pathways of exposure to the pollutant, i.e., non-dietary ingestion of particles $\left(A D D_{\text {ing }}\right)$, inhalation $\left(A D D_{\text {inh }}\right)$, and dermal absorption $\left(A D D_{\text {derm }}\right)$, were calculated with the following formulas, according to the Environmental Protection Agency of the United States (US EPA) Exposure Factors Handbook [32]:

$$
\begin{gathered}
A D D_{i n g}=\left(\mathrm{C}_{\mathrm{Hg}} \times \mathrm{IR} \times \mathrm{EF} \times \mathrm{ED} \times \mathrm{RBA} \times \mathrm{CF}\right) /(\mathrm{BW} \times \mathrm{AT}) \\
A D D_{i n h}=\left(\mathrm{C}_{\mathrm{Hg}} \times \mathrm{IR} \times \mathrm{EF} \times \mathrm{ED}\right) /(\mathrm{BW} \times \mathrm{AT} \times \mathrm{PEF}) \\
A D D_{\text {derm }}=\left(\mathrm{C}_{\mathrm{Hg}} \times \mathrm{SA} \times \mathrm{AF} \times \mathrm{ABS} \times \mathrm{EF} \times \mathrm{ED} \times \mathrm{CF}\right) /(\mathrm{BW} \times \mathrm{AT})
\end{gathered}
$$

where $\mathrm{C}_{\mathrm{Hg}}$ is the $\mathrm{Hg}$ concentration $\left(\mathrm{mg} \mathrm{kg}^{-1}\right)$ quantified in this study in the Herbarium dust; IR is the dust ingestion rate, considering two different scenarios with $30 \mathrm{mg}^{\text {day }}{ }^{-1}$ (general population central tendency) and $60 \mathrm{mg} \mathrm{day}^{-1}$ (upper 90th percentile) due to the particular conditions of this working place, where a large amount of dust is produced by the degradation of organic materials (botanical samples and paper sheets) hosted in the halls; EF is the exposure frequency (days year ${ }^{-1}$ ) assumed to be 223 days in this study, corresponding to the average number of working days per year; ED is the exposure duration (years) established to 24 years; RBA is the relative bioavailability corresponding to 1 (unitless); $\mathrm{CF}$ is the unit conversion factor $\left(10^{-6} \mathrm{~kg} \mathrm{mg}^{-1}\right)$; $\mathrm{BW}$ is the average body weight $(70 \mathrm{~kg})$; AT is the average time of exposure, calculated as $\mathrm{ED} \times 365$ days for noncarcinogenic substances; PEF is the particle emission factor $\left(1.36 \times 10^{9} \mathrm{~m}^{3} \mathrm{~kg}^{-1}\right)$; SA is the skin area $\left(1070 \mathrm{~cm}^{2}\right.$ for the hands only); AF is the skin adherence factor $\left(0.07 \mathrm{mg} \mathrm{cm}^{-2}\right)$; and ABS is the absorption factor for the skin (0.03, unitless). The coefficients IR, AT, PEF, $\mathrm{AF}$ and ABS were obtained from the US EPA [33-36]. A resume of the chosen parameters is reported in Table S1.

The hazard quotient $(H Q)$, i.e., the potential for non-carcinogenic toxicity to occur, was then calculated for each $A D D$ following the formulas below:

$$
\begin{gathered}
H Q_{\text {ing }}=A D D_{\text {ing }} / R f D_{\text {ing }} \\
H Q_{\text {inh }}=A D D_{\text {inh }} / R f D_{\text {inh }} \\
H Q_{\text {derm }}=A D D_{\text {derm }} / R f D_{\text {derm }}
\end{gathered}
$$

where $R f D$ is the specific reference dose, i.e., an estimation of the maximum permissible risk through a daily exposure [37]. The sum of the three $H Q$ s generates the hazard index (HI), i.e., the sum of multiple exposure pathways: if $\mathrm{HI}<1$ there is no risk for any pathogenic effects caused by $\mathrm{Hg}$ intake. Values of $\mathrm{HI}>1$ indicate a probability of non-carcinogenic effects, which increases as this value increases [32,33]; the toxic effects of $\mathrm{Hg}$ on human health involve neurological and behavioral disorders, systemic, reproductive and immunological toxicity, or adverse effects to the skin $[37,38]$.

\section{Results}

\subsection{Mercury Particles: Dimensions and Chemistry}

A total of 341 particles were observed and investigated for $\mathrm{Hg}$ in the Herbarium and background sites of this study using the 10-s live-time analyses. For the Herbarium, Hg-rich particles $(n=322)$ were observed in all samples (from old to new dust) collected from the Webb Hall in both the sampling campaigns. They generally occurred in clusters composed of several smaller grains (Figure 2) displaying a size distribution that followed a log-normal distribution (Figure 3a) with an average dimension of $0.79 \mu \mathrm{m}$. Rarely $(<10 \%) \mathrm{Hg}$ particles were observed to coalesce into larger grains, exceeding $1.5 \mu \mathrm{m}$ in dimension (Figure $3 \mathrm{~b}$ ). 
The smaller dimensions were always recorded in the ND, with a constant dimensional sequence in the following order: ND $<\mathrm{AD}<\mathrm{OD}$. For both sampling campaigns, the highest number of $\mathrm{Hg}$ particles was observed in the W-AD ( $n=62$ in 2018, and $n=167$ in 2020), while the lowest amounts were observed for the 2018 and W-ND ( $n=6$ and $n=2$, respectively).

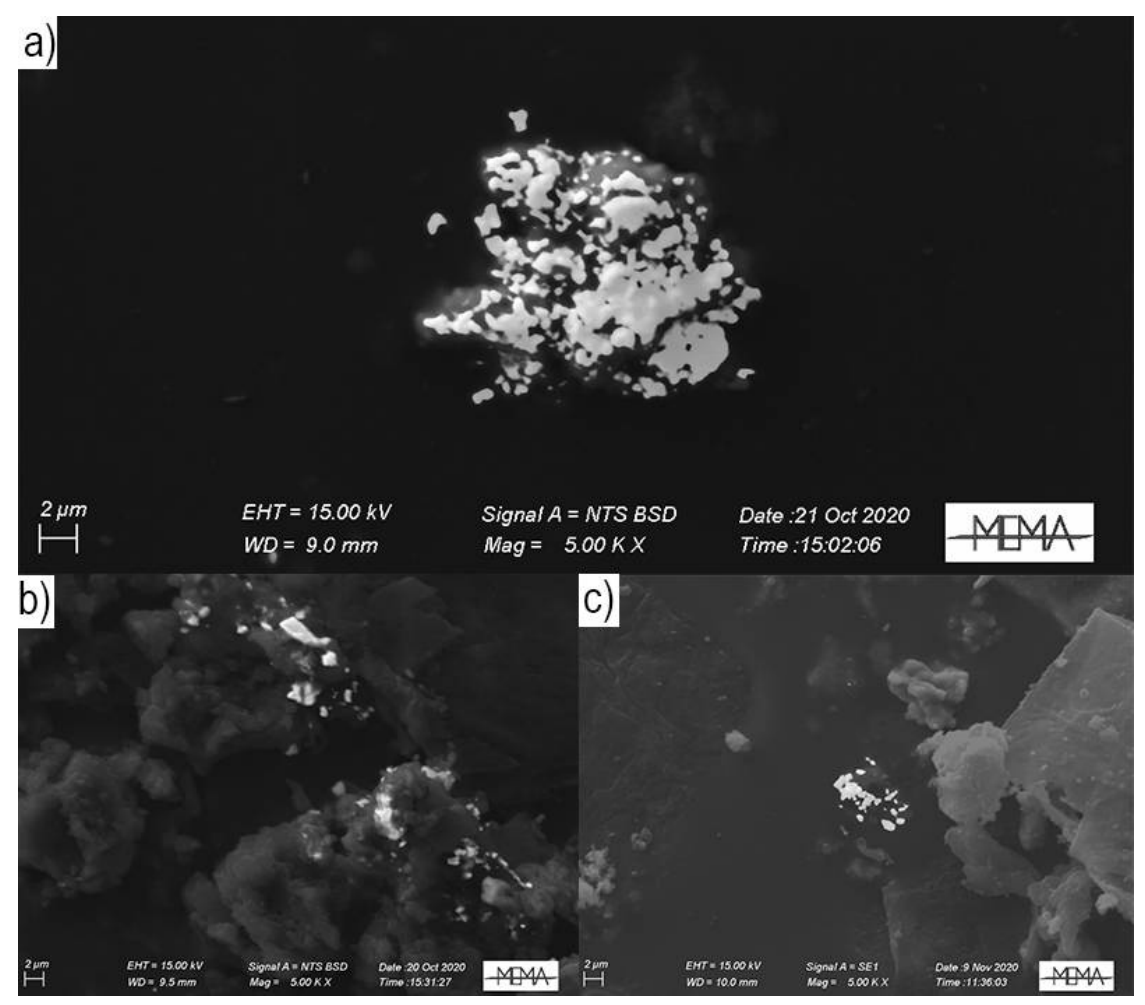

Figure 2. Mix of secondary electron (SE) and backscattered electron (BSE) images of the clusters of $\mathrm{Hg}$-particles found in (a) W-OD, (b) W-AD and (c) W-ND, respectively.

Significant differences were, however, observed between the 2018 and 2020 campaigns concerning dust average dimensions and abundances (Figure $3 c$ and Table 2). In 2018, the $\mathrm{Hg}$ particles of the Webb Hall showed an average dimension of $0.67 \mu \mathrm{m}$. More in detail, the W-AD dust displayed an ECD ranging between $0.15 \mu \mathrm{m}$ and $1.68 \mu \mathrm{m}$ (average $0.59 \mu \mathrm{m}$ ). The larger size was instead reached by W-OD, with $23 \mathrm{Hg}$ particles that showed an average $\mathrm{ECD}$ of $0.80 \mu \mathrm{m}$. The $\mathrm{W}-\mathrm{ND}$ showed the lowest number $(n=6)$ and dimension (average ECD $0.26 \mu \mathrm{m}$ ) of $\mathrm{Hg}$-particles (Figure $3 \mathrm{c}$ and Table 2).

In 2020 the Webb Hall Hg particles showed an average ECD of $0.85 \mu \mathrm{m}$ (Figure 3 and Table 2), significantly higher than the Hg particles of the 2018 samples (Mann-Whitney test $p<0.05)$. Considering the specific dust categories, the size range for $\mathrm{W}-\mathrm{AD}$ was between 0.29 and $5.90 \mu \mathrm{m}$ (average ECD $0.90 \mu \mathrm{m}$ ), statistically higher $(p<0.05)$ than the W-AD of the 2018 samples. There were $55 \mathrm{Hg}$-bearing particles in the W-ND sample, with an average ECD of $0.57 \mu \mathrm{m}$ and a maximum value of $6.25 \mu \mathrm{m}$; no statistical differences $(p>0.05)$ were observed comparing the W-ND samples from 2020 and 2018. The W-OD sample showed only $2 \mathrm{Hg}$ particles with an average ECD of $0.95 \mu \mathrm{m}$.

Regarding the dust samples collected at the background sites, only $18 \mathrm{Hg}$ particles were detected in the Botanical library, considering both years of sampling; specifically, 12 in the B-AD sample from 2018 (average ECD $0.73 \mu \mathrm{m}$ ), 4 in the B-OD 2018 sample (average $\mathrm{ECD}$ of $1.11 \mu \mathrm{m}$ ), and $2 \mathrm{Hg}$ particles in the B-OD 2020 sample. No Hg particles were found in B-ND (2018 and 2020), whereas in 2018, only one $\mathrm{Hg}$ particle was present in the G-ND sample of the Geomineralogy library (Table 2). 
a)

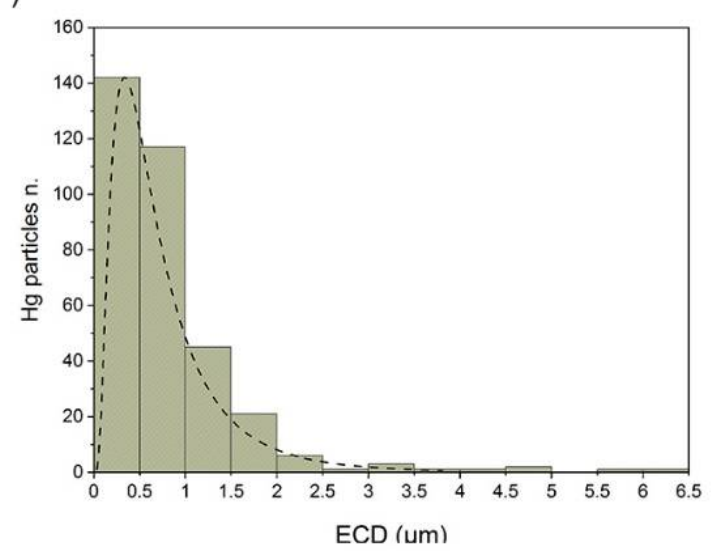

c)

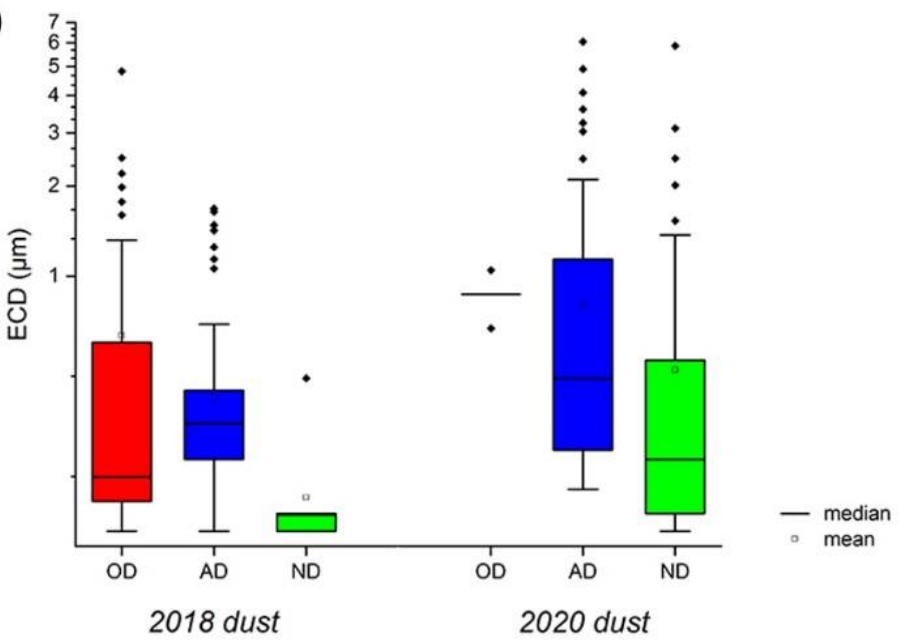

b)

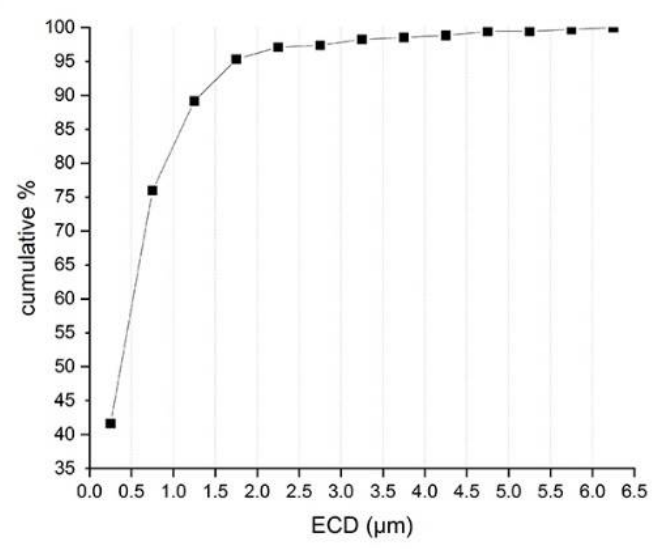

020 dust

Figure 3. (a) Frequency distribution and (b) cumulative percentage of equivalent circular diameter (ECD) of all the Hg-particles in both the 2018 and 2020 sampling campaigns; (c) particle size ranges divided by year and dust type.

Table 2. Results of the dimensional analysis of particulate bound mercury (PBM); for samples names, refer to Table 1.

\begin{tabular}{|c|c|c|c|c|c|c|c|c|c|c|}
\hline \multirow{3}{*}{ Sample } & \multicolumn{5}{|c|}{2018} & \multicolumn{5}{|c|}{2020} \\
\hline & \multicolumn{5}{|c|}{$\operatorname{ECD}(\mu \mathrm{m})$} & \multicolumn{5}{|c|}{ ECD $(\mu \mathrm{m})$} \\
\hline & Hg-Particles n. & Min & $\operatorname{Max}$ & Average & SD & Hg-Particles n. & Min & Max & Average & SD \\
\hline W-OD & 30 & 0.15 & 4.82 & 0.80 & 1.01 & 2 & 0.83 & 1.10 & 0.95 & - \\
\hline W-AD & 62 & 0.15 & 1.68 & 0.59 & 0.34 & 167 & 0.29 & 5.90 & 0.90 & 0.80 \\
\hline W-ND & 6 & 0.15 & 0.66 & 0.26 & 0.20 & 55 & 0.20 & 6.25 & 0.57 & 0.93 \\
\hline $\mathrm{W}-\mathrm{W}$ & n.a. & n.a. & n.a. & n.a. & - & - & - & - & - & - \\
\hline W-P & n.a. & n.a. & n.a. & n.a. & - & - & - & - & - & - \\
\hline B-OD & 4 & 0.83 & 1.91 & 1.11 & 0.52 & 2 & 0.51 & 2.78 & 1.65 & - \\
\hline B-AD & 12 & 0.42 & 1.44 & 0.73 & 0.36 & - & - & - & - & - \\
\hline B-ND & - & - & - & - & - & - & - & - & - & - \\
\hline B-P & n.a. & n.a. & n.a. & n.a. & - & - & - & - & - & - \\
\hline G-OD & - & - & - & - & - & - & - & - & - & - \\
\hline G-AD & - & - & - & - & - & - & - & - & - & - \\
\hline G-ND & 1 & 0.51 & 0.51 & 0.51 & - & - & - & - & - & - \\
\hline G-P & n.a. & n.a. & n.a. & n.a. & - & - & - & - & - & - \\
\hline
\end{tabular}

Similarly, no Hg particles were found in the other samples, such as wooden or paint fragments pieces collected in the Webb Hall (sample Webb-W) and in the libraries (samples W-P, B-P, and G-P). 
Interestingly, the results of the chemical characterization (30-s live-time SEM-EDS analysis) of the $\mathrm{Hg}$ particles $(n=54)$ only sporadically revealed the presence of $\mathrm{Cl}$, the original anion to which $\mathrm{Hg}$ was bound when employed on plant samples. In only one particle of the $2020 \mathrm{~W}$-OD sample $\mathrm{Hg}$ was indeed clearly associated with $\mathrm{Cl}$, and hence ascribable to a $\mathrm{Hg}$ chloride. On the contrary, the element commonly found in the $\mathrm{Hg}$ particles was $\mathrm{S}$ (Figure 4), often displaying a $\mathrm{Hg}$ to $\mathrm{S}$ molar ratio of 1:1 (Figure 5). In these particles, O was notably absent. When $\mathrm{O}$ was present in low concentrations $(\sim 20 \%$ total weight), it probably came from the $\mathrm{X}$-ray generation volume surrounding the $\mathrm{Hg}$ particles, as can be seen in Spectrum 2 of Figure 6. Similarly, we can explain the association of $\mathrm{Cu}$ to $\mathrm{Hg}$ in several sites of the $2020 \mathrm{~W}$-AD sample as a volume halo effect (Figure 6).

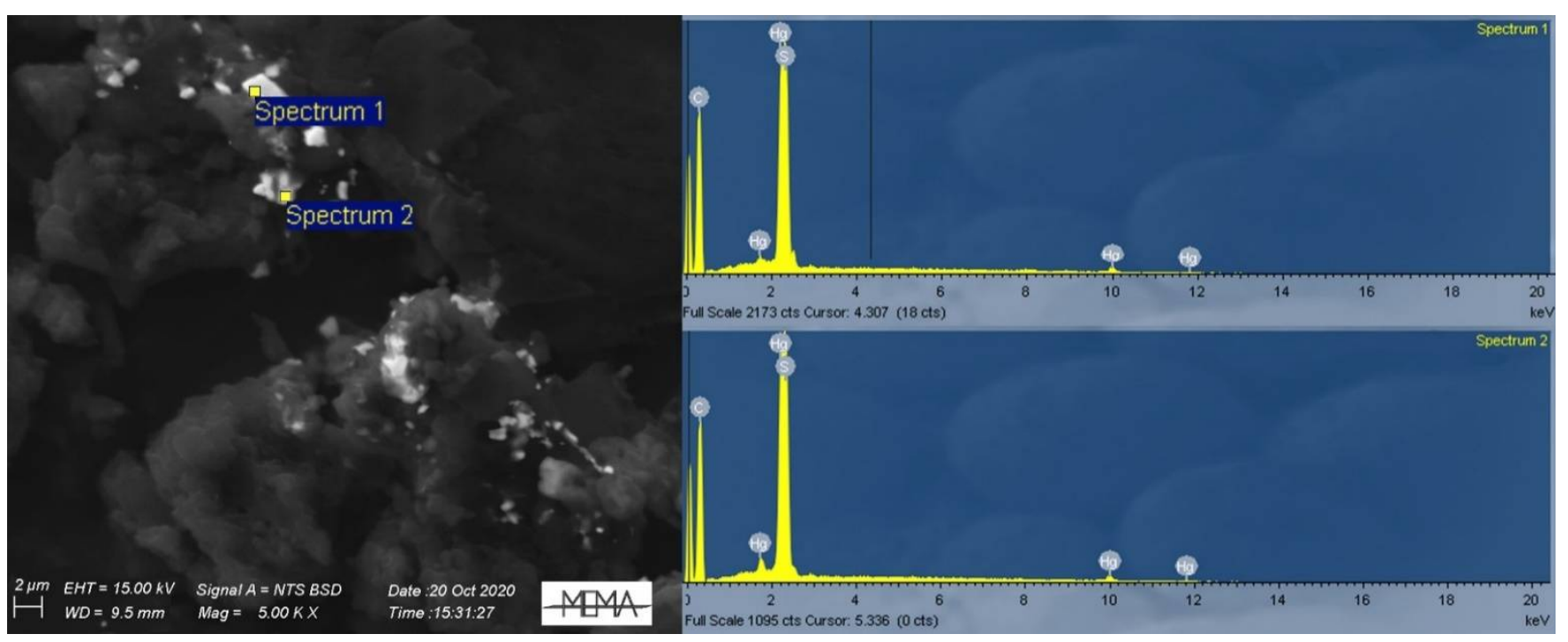

Figure 4. Mix SE and BSE image of the Hg-S compounds found in the $2020 \mathrm{~W}-\mathrm{AD}$, and the associated spectra of EDS analysis displaying $\mathrm{Hg}$ and $\mathrm{S}$.

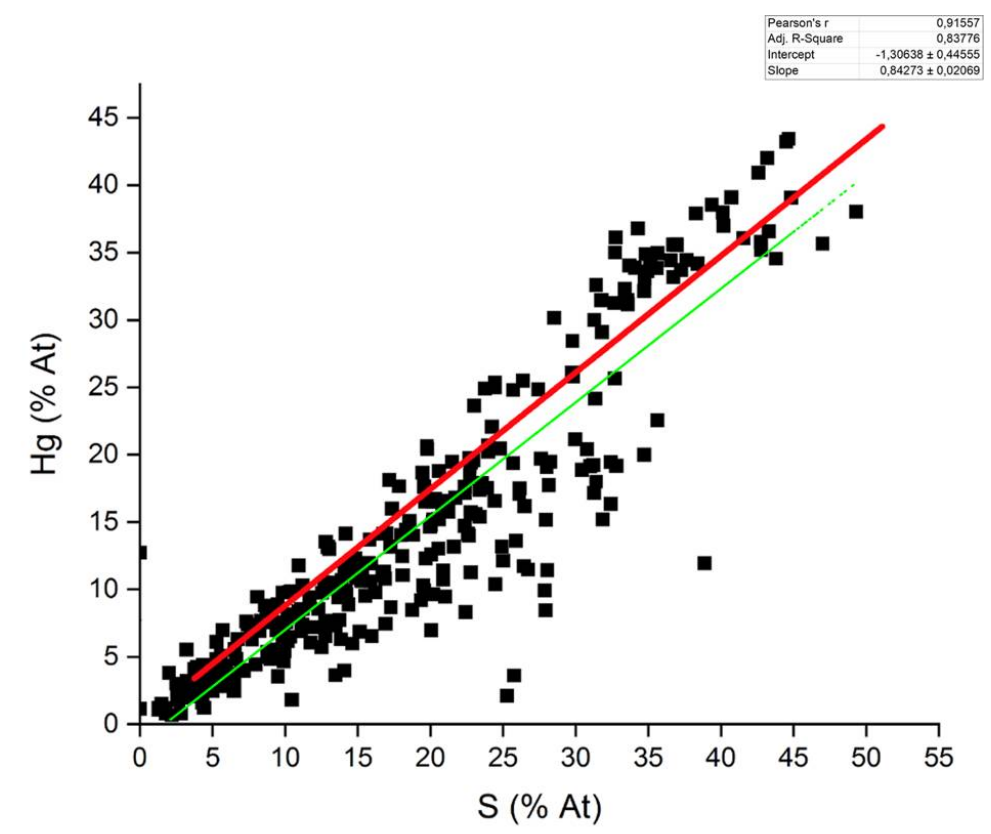

Figure 5. Atomic ratio (\% At) between $\mathrm{Hg}$ and $\mathrm{S}$ in all the $\mathrm{Hg}$ particles found in both the sampling years in the Webb Hall. Green line and the coefficients refer to the regression analysis between the percentages of the two elements, while red line refer to the hypothetical 1:1 (atomic) ratio between these elements. 


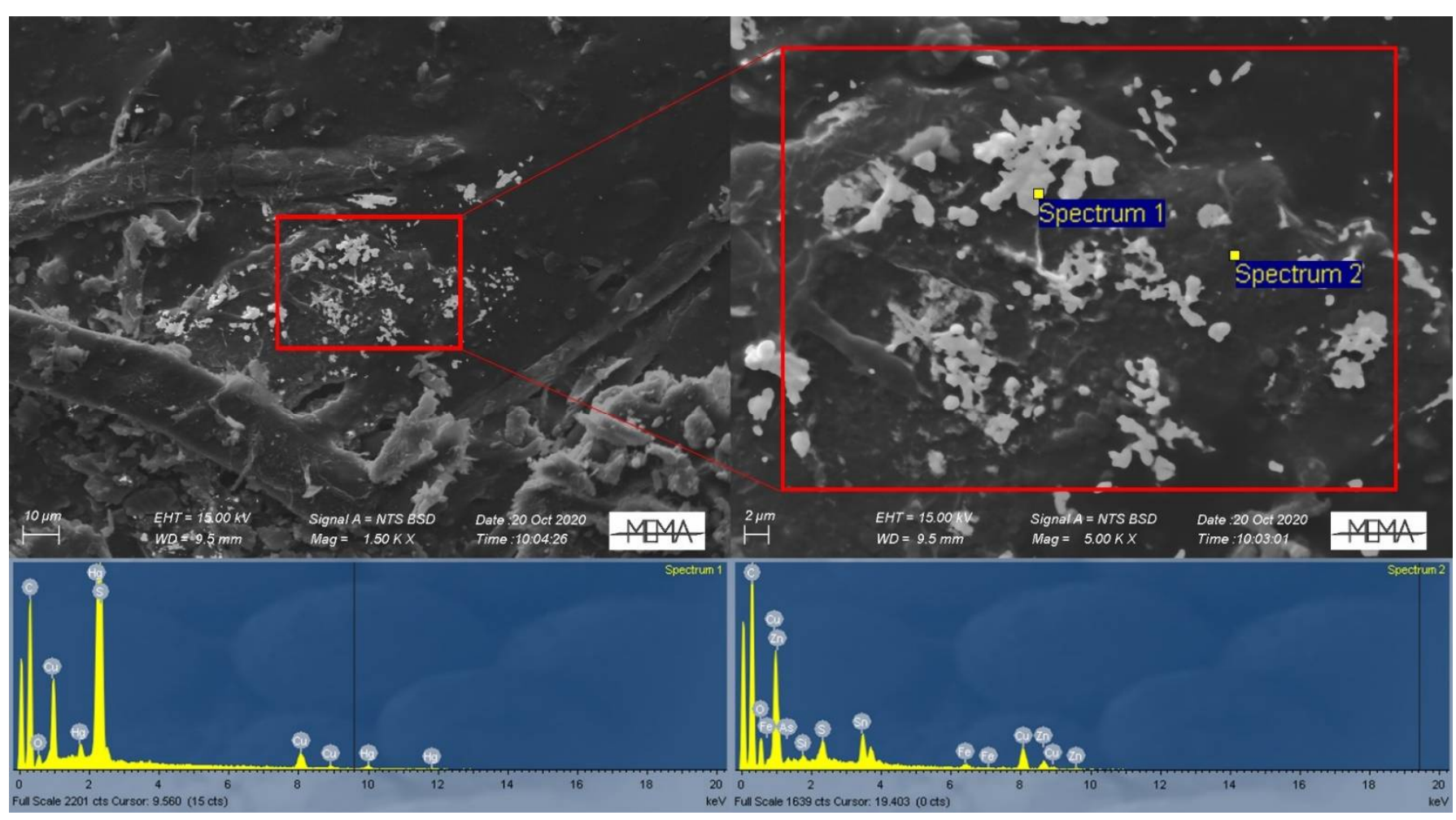

Figure 6. Detailed analysis of elemental composition of Hg particle clusters found in the 2020 W-AD (Spectrum 1) and of the area surrounding the $\mathrm{Hg}$ particles (Spectrum 2).

The total $\mathrm{Hg}$ concentration $\left(\mathrm{C}_{\mathrm{Hg}}\right)$ found in the dust samples collected in the Webb Hall varied between $151 \mathrm{mg} \mathrm{kg}^{-1}$ (minimum) to $531 \mathrm{mg} \mathrm{kg}^{-1}$ (maximum), with an average value of $329 \mathrm{mg} \mathrm{kg}^{-1}$. The dust collected in the Geomineralogy library showed an average $\mathrm{C}_{\mathrm{Hg}}$ of $13 \mathrm{mg} \mathrm{kg}^{-1}$ (min $4 \mathrm{mg} \mathrm{kg}^{-1}$, max $21 \mathrm{mg} \mathrm{kg}^{-1}$ ) (Supplementary File, Table S2).

\subsection{Other Elements}

In addition to $\mathrm{Hg}$, the heavy metals found in other dust particles of the Herbarium and blank sites were mainly $\mathrm{Zn}, \mathrm{Ba}$, and $\mathrm{Pb}$ (Supplementary File, Table S3). In the 2018 sampling year, these elements were observed in greater amounts $(n=2075$ in the Webb Hall, $n=3080$ in the libraries) than in 2020 ( $n=553$ in the Webb Hall, $n=476$ in the libraries); this decrease was especially marked for $\mathrm{Pb}$ (total $n=1532$ in 2018 samples, total $n=143$ in 2020 samples).

In the samples collected in the Webb Hall, the 2018 W-OD showed the highest number $(n=1098)$ of these three elements $(\mathrm{Zn}, \mathrm{Ba}$ and $\mathrm{Pb})$, while for the 2020 samples the highest number $(n=489)$ was reached by $W-N D$. The most represented heavy metal in both the sampling years was Ba.

In the 2018 samples, the dust particles containing heavy metals were more abundant in the libraries compared to the Herbarium halls: Zn particles were especially diffused in the Botanical library. The reverse was observed in 2020. The lowest number of heavy metal particles were always been found in the Geomineralogy library; during the 2020 campaign almost no heavy metal particles were found there.

The analysis carried on the wood pieces of a cabinet containing plant samples in the Webb Hall (sample W-W) revealed a very high level of Zn (946 particles) and Ba (930 particles), unlike the paint fragments (sample W-P) that showed only a few particles $(n=8)$ containing heavy metals. 


\section{Discussion}

\subsection{PBM Pollution in the Central Italian Herbarium}

The Hg particles of the Central Italian Herbarium are classifiable as fine particulate (i.e., PM2.5), generally showing ( $>90 \%$ ) an ECD $<1.5 \mu \mathrm{m}$ (Figure 3b). Based on the European standards for workplace atmospheres [39], this fraction must be included in the respirable one, i.e., the PM that can reach the unciliated airways tract of human lungs.

The most relevant exposure routes for PBM are inhalation and non-dietary ingestion, as well as dermal absorption by the skin [40]. The inhaled fraction is especially harmful to human health, as it can penetrate almost completely into the deepest parts of the respiratory tract, at the gas-exchange region [41]. These dangerous effects are amplified due to the possible involuntary ingestion of inorganic/organic $\mathrm{Hg}$ particles that are, respectively, partially/totally absorbed in the gastrointestinal tract [22,42]. In this regard, the analysis for health risk assessment for the dust samples collected in the Webb Hall (Supplementary File, Table S2) considering a $30 \mathrm{mg} \mathrm{day}^{-1}$ normal dust ingestion rate (the general population central tendency according to the US EPA [35]) revealed a cumulative hazard risk (HI) ranging between $0.3(\mathrm{~min})$ and $1.2(\mathrm{max})$, depending on the different concentration of $\mathrm{Hg}$ in the dust (151-531 mg kg$\left.{ }^{-1}\right)$, with an average value of 0.7 that indicates no potential adverse effects $(H I<1)$. Nevertheless, we also depicted a scenario considering an ingestion rate of $60 \mathrm{mg} \mathrm{day}^{-1}$ (the upper 90th percentile for general population), due to the special conditions of Herbarium environment, where organic samples (paper and exsiccated plants) are stored for long time and pulverized without daily cleaning practices. In this case, the $H I$ values were $>1(H I=1.2-2)$ considering the average and maximum $\mathrm{C}_{\mathrm{Hg}}$, hence indicating a significant potential risk from multipath $\mathrm{Hg}$ exposures for Herbarium workers. In the risk calculation (i.e., $H I)$, dust ingestion contributes the most $\left(H Q_{i n g}=0.9-1.5\right)$, clearly indicating involuntary ingestion as the principal exposure route to be controlled for in terms of health safety in the Herbarium museum. The $H I$ and $H Q$ values do not significantly vary, even considering specific exposures for women or men (data for women, $\mathrm{BW}=70 \mathrm{~kg} ; \mathrm{SA}=890 \mathrm{~cm}^{2}$, not shown). It should be also noted that a relative bioavailability $(\mathrm{RBA})=1$ was considered for dust ingestion, as recommended by the US EPA [43]. However, bioavailability varies considerably among $\mathrm{Hg}$ species [26] (see below), and therefore we must consider this as a precautionary measure, as the worst scenario for the protection of worker health.

On the contrary, no potential health risk $(H I<1)$ was evidenced based on the analyses of the dust samples collected from the background site, i.e., the Geomineralogy library (Supplementary File, Table S2). Even if the $\mathrm{Hg}$ concentration obtained here does not indicate a health risk, $\mathrm{Hg}$ contents are especially high when compared to those of the mean crustal values $\left(\sim 50 \mu \mathrm{g} \mathrm{kg}^{-1}\right)$, which is not surprisingly considering that indoor environments generally exceed natural concentrations or even street dust [44]. These $\mathrm{Hg}$ levels are in the upper range of those observed in house dust sampled in several residences in Ottawa (Canada) [44] or in other Chinese cities [45].

The highest amount of $\mathrm{Hg}$ particles was observed in the Herbarium hall where the most ancient plant collections of the Herbarium are conserved. Concordantly, as much as $531 \mathrm{mg} \mathrm{kg}^{-1} \mathrm{Hg}$ was observed in the room dust investigated in this study, comparable or higher than the levels observed in other museums holding natural collections [6,46]. This is especially evident on the basis of the results of the libraries samplings, where almost no $\mathrm{Hg}$ particles were found, with the exception of the botanical one, where some herbarium samples were stored in the past. As evidenced in other studies [47-49], the main sources of pollutants in PM often come from indoor contamination; therefore, an external origin must be excluded.

Data of this study clearly evidences PBM characterization being of fundamental importance for human health, especially in those contexts like the Central Italian Herbarium where gaseous forms are not the only airborne $\mathrm{Hg}$ species. In addition, it should be noted that the legislative workplace exposure limits in Italy refer to all inorganic $\mathrm{Hg}$ compounds; PBM is, therefore, included in this definition and should be quantified [50]. 
The highest number of $\mathrm{Hg}$ particles has always been found in the $\mathrm{AD}$, i.e., the dust collected inside cabinets where plant samples are stored and where GEM concentrations reach the highest values $\left(>50,000 \mathrm{ng} \mathrm{m}^{-3}\right)$ [15]; this evidence underlines that the $\mathrm{HgCl}_{2}$ treated plant collections are clearly the main pollution source and therefore Herbarium workers are particularly exposed to $\mathrm{Hg}$ when handling old samples.

It is worth noting that the number and the dimension (i.e., ECD) of particles increased over time. As evidenced by Xiu [51], the PBM formation mechanism may be due to direct emissions (from anthropogenic or natural sources) or it could be the result of adsorption of $\mathrm{Hg}$ gaseous fraction on PM and its chemical transformation. Successive changes in PBM size may be due to chemical or physical process, such as nucleation and adsorption, and environmental conditions, such as temperature and humidity [25]. In periods of scarce cleaning of surfaces, such as those following the COVID-19 pandemic lockdown in our study, $\mathrm{Hg}$ particles tended to coalesce (Figure 2). Concordantly, the newly formed dust almost always had a significantly lower dimension (Mann-Whitney test, $p<0.05$ ) than the $\mathrm{OD}$ and the $\mathrm{AD}$ of the respective years.

On the other hand, the pandemic period contributed to a drastic decrease in PBM as well as the other heavy metals in the samples taken in libraries, which is likely linked to the radical cleaning to which these rooms were subjected to re-opening to the public, especially to students.

\subsection{PBM Composition and Other Elements}

Mercury treatment of herbaria collections occurred in the form of corrosive sublimate $\left(\mathrm{HgCl}_{2}\right)$, hence a $\mathrm{Hg}$ chloride compound. After application on a plant specimen, this compound probably firstly reduces to calomel $\left(\mathrm{Hg}_{2} \mathrm{Cl}_{2}\right)$ due to its reaction with the plant matrix or water [52], and then to gaseous $\mathrm{Hg}^{0}$ via reaction with the cellulose carbonyl group of the paper supporting the plant samples [13]. This last $\mathrm{Hg}_{2} \mathrm{Cl}_{2}$ to $\mathrm{Hg}^{0}$ step was supported by the study of Passerini and Pampanini [29]; the analysis carried out by these authors revealed the presence of only $\mathrm{Hg}^{0}$ blackening the paper sheets where some plants of the Central Italian Herbarium are mounted, while, on the plant samples, calomel and organic $\mathrm{Hg}$ compounds were found. The unique Cl-rich particle of our study, with a 1:1 molar ratio, confirms the likely intermediate conversion of $\mathrm{HgCl}_{2}$ to calomel before reduction to $\mathrm{Hg}^{0}$. Except this particle, $\mathrm{Cl}$ is systematically absent from the investigated dust. As detailed by the microanalyses, the prevalent anion associated with $\mathrm{Hg}$ in the Herbarium PM was S, often in a molar ratio of approximately 1:1 with $\mathrm{Hg}$ (Figure 5), suggesting the presence of a $\mathrm{Hg}$ sulfide and the reaction of $\mathrm{Hg}$ with $\mathrm{S}$ over time. The direct association between $\mathrm{Hg}$ and $\mathrm{S}$ is also evidenced by the Figure 6 spectra, which confirms the absence of $\mathrm{S}$ from the $\mathrm{X}$-ray generation volume surrounding the $\mathrm{Hg}$ particles. The solubility and bioavailability of the $\mathrm{Hg}$ sulfide compounds were very low compared to the other $\mathrm{Hg}$ compounds; absorption of cinnabar $(\mathrm{HgS})$ by the gastrointestinal tract is very scarce $(0.05 \%)$ compared to $\mathrm{HgCl}_{2}(7-15 \%)$ and to organo-Hg compounds (almost totally absorbed) [53]. Based on these different bioavailabilities, we also depicted the risk scenario setting a RBA $=0.05$, and obtaining $H I$ indexes that were always $<1$, independently of the ingestion rates (Table S2). Full understanding of $\mathrm{Hg}$ speciation in the Herbarium dust is therefore of utmost importance.

The constant presence of $\mathrm{S}$ bound to the $\mathrm{Hg}$ particles had two possible explanations. First, we cannot rule out that $\mathrm{S}$ came from the treatments to disinfect the plants before their acquisition by the museum; Signorini [16] reported the widespread use of fumigation with $\mathrm{CS}_{2}$ on plant samples, a pest control practice carried out until the early 1970s, and also in the Central Italian Herbarium (personal communication Dr. Piero Cuccuini, former Curator of the Botanical Section of the Natural History Museum of Florence). On the other hand, based on the microanalyses conducted on the wooden fragments of a cabinet of the Webb Hall (sample Webb-W, Table S3), another S source could be represented by $\mathrm{BaSO}_{4}$. This compound was widely used since the 19th century as an inorganic synthetic pigment for white paint, particularly for lead white, but it was also employed for artistic purposes 
either in the form of blanc fixe (pure $\left.\mathrm{BaSO}_{4}\right)$ or as lithopone $\left(\mathrm{BaSO}_{4}+\mathrm{ZnS}\right)$, obtained by precipitating $\mathrm{BaSO}_{4}$ with $\mathrm{BaS}[54,55]$. Lithopone may indeed also explain the simultaneous massive presence of $\mathrm{Zn}$ and Ba in the wooden fragments of the Webb Hall (Table S3); the cabinets hosting plant samples were white painted and date back to the original period of the Herbarium's foundation (Figure 1b).

Similarly, we can explain the widespread presence of $\mathrm{Cu}$ in the $2020 \mathrm{~W}$-AD samples (Figure 6) as a derivation from the blue-green pigment associated with the packages of cardboard containing the samples (as can be seen in Figure 1e). This is probably verdigris, a mixture of copper acetate, carbonate, and chloride, which was widely used in manuscripts and early printed books until the introduction of synthetic pigments [56]. It has to be stressed that $\mathrm{Cu}$ is probably not directly associated with $\mathrm{Hg}$ particles, but it originates from the $\mathrm{X}$-ray generation volume that surrounds them (Figure 6).

Finally, the drastic reduction of Pb-particles in the 2020 samples, both from the Herbarium and from libraries has to be underlined (Table S3). Unlike the other elements, for which an internal source of contamination is easily presumed, for $\mathrm{Pb}$, the contamination could come from outdoor environments [57]. From this point of view, it should be noted that Herbarium rooms are not hermetically closed, and there is a ventilation and air recirculation system that could be the cause of contamination from the outside. However, despite a general decrease of $\mathrm{Pb}$ being observed in the outdoors during the pandemic period [58,59], in our case we can probably exclude this origin. One of the major causes of indoor $\mathrm{Pb}$ pollution, excluding cooking and tobacco smoking, is the use of old Pb-based paints [60], but in our case, the microanalyses of the fragments scrapped from the wall (sample W-P) and from the cabinet wood of the Webb Hall (sample W-W) do not support this hypothesis. The causes of $\mathrm{Pb}$ reduction are not entirely clear; perhaps, $\mathrm{Pb}$-sources (probably rooms painted with Pb-based paints) are present in the building hosting both the Herbarium and the libraries and, differently from PBM - the scarce attendance during the first months of 2020 may have influenced the decrease of the indoor $\mathrm{Pb}$ levels.

\section{Conclusions}

The results of the present study clearly indicate that PBM constitutes a non-negligible source of $\mathrm{Hg}$ pollution that affects the Central Italian Herbarium atmosphere; preliminary information about PBM dimensional and elemental characteristics have been collected.

The PBM size range is almost totally $(>95 \%)$ classifiable as fine particulate $(\leq 2.5 \mu \mathrm{m})$, particularly harmful to human health, although a dimensional increase likely associates with time due to the coalescence phenomena. As well as the size range, the chemical composition also changed over time, underlying that $\mathrm{HgCl}_{2}$ solution used to treat plant samples still sublimates. Sulfur availability in the environment, possibly due to fumigation treatments of plant specimens with $\mathrm{CS}_{2}$ and/or the employment of $\mathrm{BaSO}_{4}$ as white pigment in the Webb Hall favors $\mathrm{Hg}$ recombination with $\mathrm{S}$ and the precipitation of $\mathrm{Hg}$ sulfide, which is, at present, the main $\mathrm{Hg}$ species found in PBM.

In the worst-case scenario $(100 \%$ bioavailability of $\mathrm{Hg})$, the risk analysis for PBM indicates a multiway exposure risk for human health; among these, the main dangerous pathway is ingestion, suggesting that Herbarium workers should avoid any activity that promotes involuntary dust intake (for example drinking or eating in the Museum halls), as well as wearing safety equipment (such as gloves and lab coats) when attending these rooms. Fortunately, data of this study suggest a lower bioavailability of $\mathrm{Hg}$ species in Herbarium dust (i.e., $\mathrm{Hg}$ sulfides), which should consistently lower the health risk for workers in the Museum. Further studies to fully elucidate the $\mathrm{Hg}$ mineral phases in the Herbarium dust are planned for the near future.

This research provides information on an abatement system that could be installed to reduce the $\mathrm{Hg}$ pollution (i.e., gaseous and particulate fraction) that affects the Herbarium. This would need to be supplied with filters able to retain fine PM. In addition, the proper management of plant samples could be of fundamental importance to reduce the health risks for both Herbarium workers and visitors. 
Supplementary Materials: The following are available online at https://www.mdpi.com/article/10 .3390 / toxics $9060141 /$ s1, Table S1: Summary of the parameters employed for dust ingestion $\left(A D D_{\text {ing }}\right)$, inhalation $\left(A D D_{i n h}\right)$, and dermal absorption $\left(A D D_{\text {derm }}\right)$ calculation, Table S2: Results of the hazard quotients $(H Q)$ for the three different exposure pathways (ingestion, inhalation and dermal absorption) and the calculated hazard index (HI) for the dust samples collected in the Central Italian Herbarium and in the Geomineralogy library (the background site), Table S3: Results of the dimensional analysis of the other heavy metals found in the samples dust of both years.

Author Contributions: Conceptualization, V.R. and P.C.; methodology, V.R. and L.C.; software, L.C.; formal analysis, L.C. and F.C.; investigation, L.C.; data curation, F.C.; writing-original draft preparation, F.C.; writing-review and editing, V.R., P.C. and F.C.; visualization, F.C.; supervision, V.R. and P.C.; project administration, V.R. All authors have read and agreed to the published version of the manuscript.

Funding: This research received was founded by Fondazione Ente Cassa Risparmio di Firenze (grant number 2019.0702).

Institutional Review Board Statement: Not applicable.

Informed Consent Statement: Not applicable.

Data Availability Statement: All supporting data have been included in this study, and are available from the corresponding authors upon request.

Acknowledgments: The authors want to thank all the staff of the Central Italian Herbarium (Natural History Museum of the University of Florence) for providing useful information and support and the anonymous reviewers for their useful suggestions that greatly improved the article.

Conflicts of Interest: The authors declare no conflict of interest.

\section{References}

1. Kurt-Karakus, P.B. Determination of heavy metals in indoor dust from Istanbul, Turkey: Estimation of the health risk. Environ. Int. 2012, 50, 47-55. [CrossRef]

2. Hulin, M.; Simoni, M.; Viegi, G.; Annesi-Maesano, I. Respiratory health and indoor air pollutants based on quantitative exposure assessments. Eur. Respir. J. 2012, 40, 1033-1045. [CrossRef]

3. Schieweck, A.; Lohrengel, B.; Siwinski, N.; Genning, C.; Salthammer, T. Organic and inorganic pollutants in storage rooms of the lower Saxony state museum Hanover, Germany. Atmos. Environ. 2005, 39, 6098-6108. [CrossRef]

4. Ali, H.; Khan, E. What are heavy metals? Long-standing controversy over the scientific use of the term 'heavy metals'-proposal of a comprehensive definition. Toxicol. Environ. Chem. 2018, 100, 6-19. [CrossRef]

5. Lummas, S.; Ruiz-Jimenez, J.; de Castro, M.D.L.; Colston, B.; Gonzalez-Rodriguez, J.; Chen, B.; Corns, W. Determination of arsenic, mercury and barium in herbarium mount paper using dynamic ultrasound-assisted extraction prior to atomic fluorescence and absorption spectrometry. Anal. Lett. 2011, 44, 1842-1852. [CrossRef]

6. Marcotte, S.; Estel, L.; Minchin, S.; Leboucher, S.; Le Meur, S. Monitoring of lead, arsenic and mercury in the indoor air and settled dust in the Natural History Museum of Rouen (France). Atmos. Pollut. Res. 2017, 8, 483-489. [CrossRef]

7. Briggs, D.; Sell, P.D.; Block, M.; I'ons, R.D. Mercury vapour: A health hazard in herbaria. New Phytol. 1983, 94, 453-457. [CrossRef]

8. Hawks, C.; Makos, K.; Bell, D.; Wambach, P.E.; Burroughs, G.E. An inexpensive method to test for mercury vapor in herbarium cabinets. Taxon 2004, 53, 783-790. [CrossRef]

9. Oyarzun, R.; Higueras, P.; Esbrí, J.M.; Pizarro, J. Mercury in air and plant specimens in herbaria: A pilot study at the MAF Herbarium in Madrid (Spain). Sci. Total Environ. 2007, 387, 346-352. [CrossRef] [PubMed]

10. Kataeva, M.; Panichev, N.; van Wyk, A.E. Monitoring mercury in two South African herbaria. Sci. Total Environ. 2009, 407, 1211-1217. [CrossRef]

11. Fellowes, J.W.; Pattrick, R.A.D.; Green, D.I.; Dent, A.; Lloyd, J.R.; Pearce, C.I. Use of biogenic and abiotic elemental selenium nanospheres to sequester elemental mercury released from mercury contaminated museum specimens. J. Hazard. Mater. 2011, 189, 660-669. [CrossRef]

12. Webber, W.B.; Ernest, L.J.; Vangapandu, S. Mercury exposures in university herbarium collections. J. Chem. Health 2011, 18, 9-12. [CrossRef]

13. Havermans, J.; Dekker, R.; Sportel, R. The effect of mercuric chloride treatment as biocide for herbaria on the indoor air quality. Herit. Sci. 2015, 3, 39. [CrossRef]

14. Fallon, D.; Peters, M.; Hunt, M.; Koehler, K. Cleaning protocol for mercuric chloride-contaminated herbarium cabinets at the Smithsonian Museum Support Center. In Collection Forum; The Society for the Experimental Analysis of Behavior, Inc.: Marthasville, MO, USA; Department of Psychology, Indiana University: Bloomington, IN, USA, 2016; Volume 30, pp. 51-62. [CrossRef] 
15. Cabassi, J.; Rimondi, V.; Yeqing, Z.; Vacca, A.; Vaselli, O.; Buccianti, A.; Costagliola, P. 100 years of high GEM concentration in the Central Italian Herbarium and Tropical Herbarium Studies Centre (Florence, Italy). J. Environ. Sci. 2020, 87, 377-388. [CrossRef] [PubMed]

16. Signorini, M.A. La difesa degli erbari dai parassiti: Indagine sulle caratteristiche e la sicurezza d'uso dei principali mezzi di lotta adottati. Mus. Sci. 1984, 1-2, 29-54.

17. World Health Organization (WHO). Air Quality Guidelines for Europe, 2nd ed.; WHO Regional Publications, European Series; World Health Organization, Regional Office for Europe: Geneva, Switzerland, 2000.

18. Gustin, M.S.; Biester, H.; Kim, C.S. Investigation of the light-enhanced emission of mercury from naturally enriched substrates. Atmos. Environ. 2002, 36, 3241-3254. [CrossRef]

19. Scholtz, M.T.; Van Heyst, B.J.; Schroeder, W.H. Modelling of mercury emissions from background soils. Sci. Total Environ. 2003, 304, 185-207. [CrossRef]

20. Rudnick, R.L.; Gao, S.; Holland, H.D.; Turekian, K.K. Composition of the continental crust. In The Crust; Holland, H.D., Turekian, K.K., Eds.; University of Maryland: Maryland, MD, USA, 2003; Volume 3, pp. 1-64.

21. Schroeder, W.H.; Munthe, J. Atmospheric mercury-An overview. Atmos. Environ. 1998, 29, 809-822. [CrossRef]

22. Park, J.D.; Zheng, W. Human exposure and health effects of inorganic and elemental mercury. J. Prev. Med. Public Health 2012, 45, 344. [CrossRef]

23. Lynam, M.M.; Keeler, G.J. Comparison of methods for particulate phase mercury analysis: Sampling and analysis. Anal. Bioanal. Chem. 2002, 374, 1009-1014. [CrossRef]

24. Selin, E.S. Atmospheric Chemistry, Modeling, and Biogeochemistry of Mercury. In Mercury in the Environment: Pattern and Process; Bank, M.S., Ed.; University of California Press: Berkeley, CA, USA, 2012.

25. Kim, P.R.; Han, Y.J.; Holsen, T.M.; Yi, S.M. Atmospheric particulate mercury: Concentrations and size distributions. Atmos. Environ. 2012, 61, 94-102. [CrossRef]

26. Lu, J.Y.; Schroeder, W.H. Sampling and determination of particulate mercury in ambient air: A review. Water Air Soil Pollut. 1999, 112, 279-295. [CrossRef]

27. Raffaelli, M. Il Museo di Storia Naturale dell'Università di Firenze. Le Collezioni Botaniche; Firenze University Press: Firenze, Italy, 2009.

28. Thiers, B.M. The World's Herbaria 2017: A Summary Reported Based on Data from Index Herbariorum; NYBG: Bronx, NY, USA, 2018.

29. Passerini, N.; Pampanini, R. La conservazione degli erbari e l'efficacia del sublimato ( $\mathrm{HgCl} 2)$ nell'avvelenamento delle piante. Soc. Bot. Ital. 1927, 34, 593-627.

30. Goldstein, J.; Newbury, D.E.; Joy, D.C.; Lyman, C.E.; Echlin, P.; Lifshin, E.; Sawyer, L.; Michael, J.R. Scanning Electron Microscopy and X-Ray Microanalysis, 3rd ed.; Springer: New York, NY, USA, 2003.

31. R Core Team. R: A Language and Environment for Statistical Computing; R Foundation for Statistical Computing: Vienna, Austria, 2018.

32. US EPA (Environmental Protection Agency). Exposure Factors Handbook: 2011 Edition; EPA/600/R-09/052F; National Center for Environmental Assessment: Washington, DC, USA, 2011.

33. US EPA (Environmental Protection Agency). Supplemental Guidance for Developing Soil Screening Levels for Superfund Sites; EPA/540/R-96/018; Office of Solid Waste and Emergency Response: Washington, DC, USA, 2002.

34. US EPA (Environmental Protection Agency). Risk Assessment Guidance for Superfund Volume I: Human Health Evaluation Manual (Part E, Supplemental Guidance for Dermal Risk Assessment); EPA/540/R/99/005; Office of Superfund Remediation and Technology Innovation, US Environmental Protection Agency: Washington, DC, USA, 2004.

35. US EPA (Environmental Protection Agency). Update for Chapter 5 of the Exposure Factors Handbook Soil and Dust Ingestion EPA/600/R-17/384F; National Center for Environmental Assessment Office of Research and Development US Environmental Protection Agency: Washington, DC, USA, 2017.

36. RAIS (The Risk Assessment Information System). Condensed Toxicity Summary for Mercury. Available online: https://rais.ornl. gov/tox/profiles/mercury_c_V1.html (accessed on 1 April 2021).

37. US EPA (Environmental Protection Agency). Sustainable Futures/P2 Framework Manual, Risk Assessment Division of the Office of Pollution Prevention and Toxics; EPA-748-B12-001; US Environmental Protection Agency (EPA/OPPT): Washington, DC, USA, 2012.

38. World Health Organization (WHO). Guidance for Identifying Populations at Risk from Mercury Exposure; Mercury Publications: New York, NY, USA, 2016.

39. European Committee for Standardization (CEN). Workplace Atmospheres-Size Fraction Definitions for Measurement of Airborne Particles; Report No. BS EN 481; CEN, British Standards Institute: London, UK, 1993.

40. Schleicher, N.J.; Schäfer, J.; Chen, Y.; Blanc, G.; Chen, Y.; Chai, F.; Cen, K.; Norra, S. Atmospheric particulate mercury in the megacity Beijing: Efficiency of mitigation measures and assessment of health effects. Atmos. Environ. 2016, 124, 396-403. [CrossRef]

41. Brown, J.S.; Gordon, T.; Price, O.; Asgharian, B. Thoracic and respirable particle definitions for human health risk assessment. Part. Fibre Toxicol. 2013, 10, 1-12. [CrossRef]

42. Hong, Y.S.; Kim, Y.M.; Lee, K.E. Methylmercury exposure and health effects. J. Prev. Med. Public Health 2012, 45, 353. [CrossRef]

43. US EPA (Environmental Protection Agency). Guidance for Evaluating the Oral Bioavailability of Metals in Soils for Use in Human Health Risk Assessment; United States Environmental Protection Agency, OSWER: Washington, DC, USA, 2007 ; pp. 7-80. 
44. Rasmussen, P.E.; Subramanian, K.S.; Jessiman, B.J. A multi-element profile of house dust in relation to exterior dust and soils in the city of Ottawa, Canada. Sci. Total Environ. 2001, 267, 125-140. [CrossRef]

45. Wang, W.; Wu, F.; Zheng, J.; Wong, M.H. Risk assessments of PAHs and Hg exposure via settled house dust and street dust, linking with their correlations in human hair. J. Hazard. Mater. 2013, 263, 627-637. [CrossRef]

46. Deering, K.; Spiegel, E.; Quaisser, C.; Nowak, D.; Schierl, R.; Bose-O'Reilly, S.; Garí, M. Monitoring of arsenic, mercury and organic pesticides in particulate matter, ambient air and settled dust in natural history collections taking the example of the Museum für Naturkunde, Berlin. Environ. Monit. Assess. 2019, 191, 1-17. [CrossRef]

47. Jaradat, Q.M.; Momani, K.A.; Jbarah, A.A.Q.; Massadeh, A. Inorganic analysis of dust fall and office dust in an industrial area of Jordan. Environ. Res. 2004, 96, 139-144. [CrossRef] [PubMed]

48. Kopperud, R.J.; Ferro, A.R.; Hildemann, L.M. Outdoor versus indoor contributions to indoor particulate matter (PM) determined by mass balance methods. J. Air Waste Manag. Assoc. 2004, 54, 1188-1196. [CrossRef] [PubMed]

49. Zhong, J.N.M.; Latif, M.T.; Mohamad, N.; Wahid, N.B.A.; Dominick, D.; Juahir, H. Source apportionment of particulate matter $\left(\mathrm{PM}_{10}\right)$ and indoor dust in a university building. Environ. Forensics 2014, 15, 8-16. [CrossRef]

50. Ciani, F.; Rimondi, V.; Costagliola, P. Atmospheric mercury pollution: The current methodological framework outlined by environmental legislation. Air Qual. Atmos. Health 2021, 1-13. [CrossRef]

51. Xiu, G.L.; Jin, Q.; Zhang, D.; Shi, S.; Huang, X.; Zhang, W.; Bao, L.; Gao, P.; Chen, B. Characterization of size-fractionated particulate mercury in Shanghai ambient air. Atmos. Environ. 2005, 39, 419-427. [CrossRef]

52. Duffour, E. Note sur un proceed simplifiè pour l'empoisonnement des plantes d'herbier à l'aide de la dissolution alcoolique de Richlorure de Mercure. Bull. Soc. Bot. Fr. 1863, 10, 686. [CrossRef]

53. Welfringer, B.; Zagury, G.J. Evaluation of two in vitro protocols for determination of mercury bioaccessibility: Influence of mercury fractionation and soil properties. J. Environ. Qual. 2009, 38, 2237-2244. [CrossRef]

54. Bacci, M.; Picollo, M.; Trumpy, G.; Tsukada, M.; Kunzelman, D. Non-invasive identification of white pigments on 20th-century oil paintings by using fiber optic reflectance spectroscopy. J. Am. Inst. Conserv. 2007, 46, 27-37. [CrossRef]

55. Harroun, S.G.; Bergman, J.; Jablonski, E.; Brosseau, C.L. Surface-enhanced Raman spectroscopy analysis of house paint and wallpaper samples from an 18th century historic property. Analyst 2011, 136, 3453-3460. [CrossRef]

56. Hofmann, C.; Hartl, A.; Ahn, K.; Faerber, I.; Henniges, U.; Potthast, A. Studies on the Conservation of Verdigris on Paper. Int. J. Preserv. Libr. Arch. Mater. 2015, 36, 147-182. [CrossRef]

57. Zwoździak, A.; Sówka, I.; Krupińska, B.; Zwoździak, J.; Nych, A. Infiltration or indoor sources as determinants of the elemental composition of particulate matter inside a school in Wrocław, Poland. Build. Environ. 2013, 66, 173-180. [CrossRef]

58. Rodríguez-Urrego, D.; Rodríguez-Urrego, L. Air quality during the COVID-19: $\mathrm{PM}_{2.5}$ analysis in the 50 most polluted capital cities in the world. Environ. Pollut. 2020, 266, 115042. [CrossRef] [PubMed]

59. Zheng, H.; Kong, S.; Chen, N.; Yan, Y.; Liu, D.; Zhu, B.; Xu, K.; Cao, W.; Ding, Q.; Lan, B.; et al. Significant changes in the chemical compositions and sources of $\mathrm{PM}_{2.5}$ in Wuhan since the city lockdown as COVID-19. Sci. Total Environ. 2020, 739, 140000. [CrossRef] [PubMed]

60. Agency For Toxic Substances and Disease Registry (ATSDR). Lead Toxicity. 2017. Available online: https://www.atsdr.cdc.gov / csem/lead/docs/CSEM-Lead_toxicity_508.pdf (accessed on 1 February 2021). 